\title{
Seismically-induced soft-sediment deformation in crevasse-splay microdelta deposits (Middle Miocene, central Poland)
}

\author{
Lilianna CHOMIAK ${ }^{1}$, Piotr MACIASZEK ${ }^{1}$, Robert WACHOCKI ${ }^{2}$, \\ Marek WIDERA ${ }^{1, *}$ and Tomasz ZIELIŃSKI ${ }^{1}$
}

\author{
1 Adam Mickiewicz University, Institute of Geology, Krygowski 12, 61-680 Poznań, Poland
}

2 Konin Lignite Mine, al. 600-lecia 9, 62-540 Kleczew, Poland

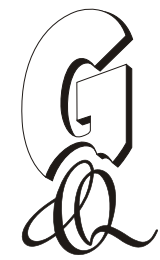

Chomiak, L., Maciaszek, P., Wachocki, R., Widera, M., Zieliński, T., 2019. Seismically-induced soft-sediment deformation in crevasse-splay microdelta deposits (Middle Miocene, central Poland). Geological Quarterly, 63 (1): 162-177, doi: 10.7306/gq. 1456

Associate editor: Anna Wysocka

Crevasse-splay microdelta deposits and their soft-sediment deformation structures (SSDS) are described from a tectonically active lignite-bearing area. These strongly deformed siliciclastic deposits, situated between two lignite benches, are typical of a crevasse-splay microdelta. They accumulated in the overbank zone of a Middle Miocene river system (backswamp area) where shallow ponds or lakes occasionally existed. The deformation takes the form of deformed lamination and load (load casts and flame structures) structures as well as seismic breccias within the first Mid-Polish lignite seam. Ductile deformation structures were generated first by liquefaction and then the breccia was formed under brittle conditions. The brecciation followed a sudden tectonic collapse resulting in an increase in pore pressure related to upward water movement. The occurrence in a tectonic graben and characteristic morphological features suggest an origin of these deformational structures with seismic shocks; thus, they can be called seismites. Hence, we provide strong evidence for accumulation of crevasse-splay sediments in the standing water of a backswamp area, and for tectonic activity in central Poland as the Middle Miocene lignite accumulated.

Key words: backswamp area, SSDS, ductile and brittle deformations, earthquakes, seismites.

\section{INTRODUCTION}

Siliciclastic intercalations, or in general terms, interbeds of mineral deposits (sands, clays, lacustrine limestones, tonsteins, etc.) within peat-to-coal seams are very common in both modern and ancient sedimentary successions (e.g., Horne et al., 1978; Kasiński, 1989; Schäfer et al., 1995; Słomka et al., 2000; Uličný et al., 2000; Holdgate, 2005; Opluštil, 2005; Rajchl and Uličný, 2005; Rajchl et al., 2008; Flores, 2013; Mach et al., 2013; Mastej et al., 2015 and references therein). In most cases, they form sheet-like sandy bodies that are interpreted as crevasse splays (e.g., Guion, 1984; McCabe, 1984; Fielding, 1986; Kasiński, 1986; Kirschbaum and McCabe, 1992; Flores, 1993; Smith and Pérez-Arlucea, 1994; Pérez-Arlucea and Smith, 1999; Diessel et al., 2000; Davies-Vollum and Kraus, 2001; Farrell, 2001; Gouw and Autin, 2008; Van Asselen et al., 2009; Cahoon et al., 2011; Widera, 2016a; Widera et al.,

\footnotetext{
* Corresponding author, e-mail: widera@amu.edu.pl
}

Received: October 10, 2018; accepted: January 28, 2019; first published online: March 14, 2019 2017a). The crevasse splays are created when natural levees are breached during the initial phase of overbank flooding (e.g., Smith et al., 1989; Farrell, 2001; Bridge, 2003; Zieliński, 2014; Toonen et al., 2016). Thus, their sediments mainly accumulated in subaerial environments and less frequently in subaqueous conditions, that is, in standing water (ponds or lakes), that exist on a floodplain (backswamp) in close proximity to an active (meandering or anastomosing) river channel (Horne et al., 1978; Tye and Coleman, 1989; Michaelsen et al., 2000; Gębica and Sokołowski, 2001; Bos et al., 2009). In the latter case, this is shown by the presence of steeply dipping layers typical of "prograding splay deposits" (sensu Bristow et al., 1999), representing a crevasse-splay microdelta (Michaelsen et al., 2000; Zieliński, 2014). Such deposits, with well-developed foreset laminae, are well exposed in the Jóźwin IIB lignite opencast mine in central Poland (Fig. 1).

Both crevasse-splay sediments (but not a crevasse-splay microdelta) and breccia (but not of tectonic origin) are known from the nearby Tomisławice lignite opencast mine (Fig. 1A; Widera, 2016a, 2017; Widera et al., 2017a). Seismically-induced breccias and plastic deformation structures not related to crevasse splays are also known from other Polish lignite-bearing areas (e.g., van Loon et al., 1995; Gruszka and Zieliński, 1996; Gruszka and van Loon, 2007; Widera and Hałuszczak, 


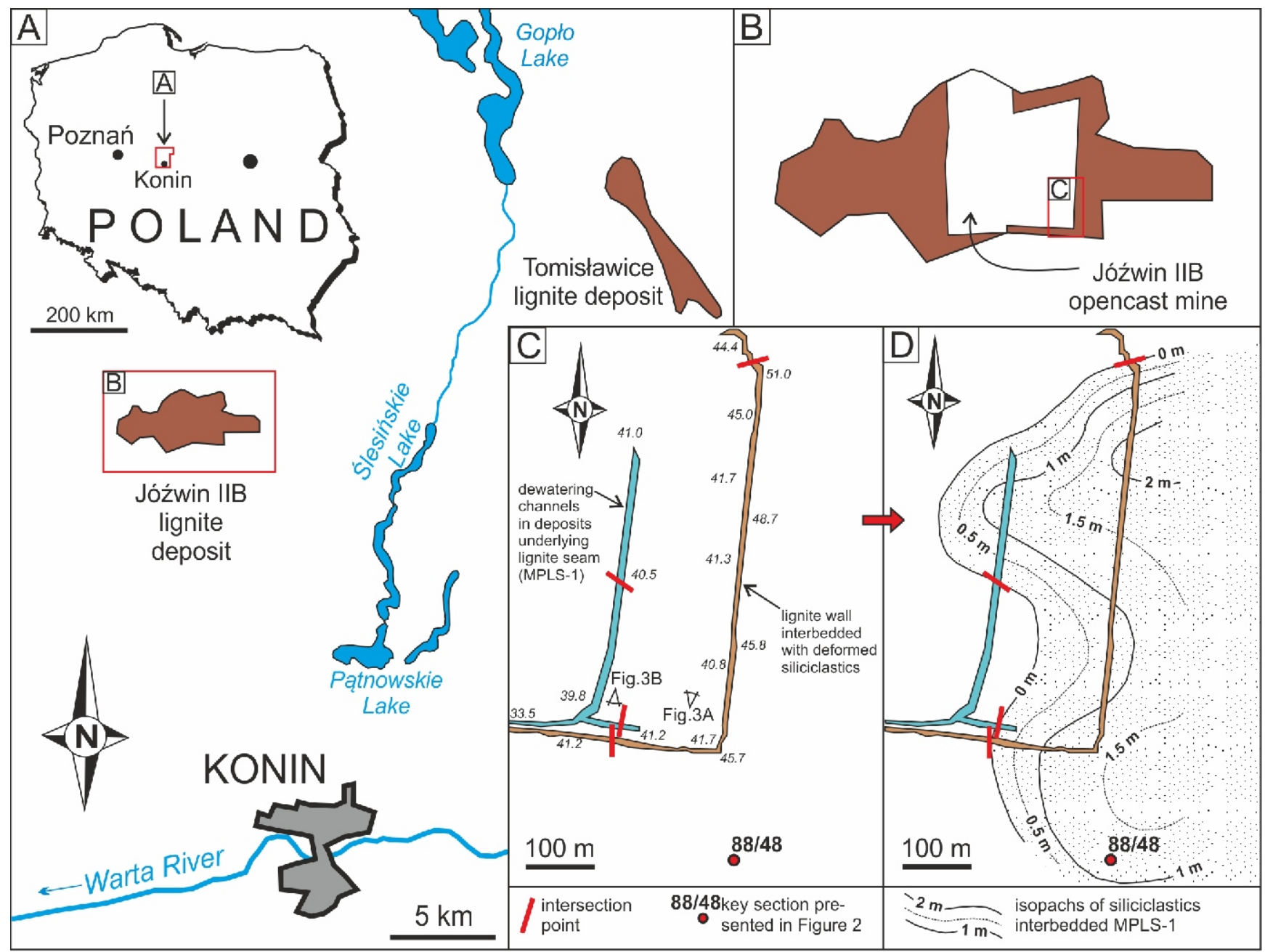

Fig. 1. Location of the study area

A - location on a map of Poland; B - outline of the Jóźwin IIB lignite deposits (52 $\left.40^{\prime} 11^{\prime \prime} \mathrm{N}, 18^{\circ} 17^{\prime} 44^{\prime \prime} \mathrm{E}\right)$; C - mapped lignite walls and dewatering channels at the lowermost exploitation level in May and June 2018; D - approximate extent of the siliciclastic deposits examined within the first Mid-Polish lignite seam (MPLS-1); intersection point marks the margin of siliciclastic deposits within the lignite seam (MPLS-1) mapped in the field; note location of the key section (borehole no. 88/48) used to show the Cenozoic stratigraphy of the study area shown in Figure 2

2011). Moreover, plastic soft-sediment deformation structures have been described from other delta and crevasse-splay successions (e.g., Uličný et al., 2000; Mach et al, 2013; Burns et al., 2017). Wholly deformed deposits of a crevasse-splay microdelta seem not have been described until now.

This paper therefore: (1) describes and interprets the clastic facies of the crevasse-splay succession; (2) identifies all softsediment deformation structures present and characterises the mechanism of their origin; and (3) proposes a conceptual model for the crevasse-splay and deformation structures formed during peat accumulation in Middle Miocene mires, which transformed into the first Mid-Polish lignite seam in central Poland.

\section{GEOLOGICAL SETTING}

The study area, that is, the Jóźwin IIB lignite opencast mine, where the strongly disturbed siliciclastic deposits are exposed comprises the northernmost part of the Kleczew Graben. This fault-bounded shallow tectonic depression is located several kilometres north of Konin in central Poland (Fig. 1). The Mesozoic bedrock of the graben, which occurs at a depth of up to a few tens of metres, is built of limy sandstones of Late Cretaceous age (Widera, 2007, 2014). The entire Paleogene is represented by a stratigraphic gap; so far, deposits of this age have not been found in this territory. Around the Paleogene/Neogene boundary, the Cenozoic evolution of the Kleczew Graben began (Widera, 2007). Thus, in this area only Neogene and Quaternary successions are present (Fig. 2; Widera, 2014; Widera et al., 2017b).

The Neogene consists of two lithostratigraphic formations: the Koźmin Formation overlain by the Poznań Formation. The Koźmin Formation of earliest to Middle Miocene age is composed of fluvio-lacustrine sand and silt deposits with lignite interbeds (Widera, 2007). It is capped by the Poznań Formation of Middle Miocene to Early Pliocene age. This formation is divided into two lithostratigraphic members from its lithological and genetic diversity; the lower Grey Clays Member and the upper Wielkopolska Member (Fig 2; Piwocki and ZiembińskaTworzydło, 1997; Widera 2013a).

The Grey Clays Member, called also the Mid-Polish Member, contains the first Mid-Polish lignite seam (MPLS-1), which is $3-13 \mathrm{~m}$ thick, averaging $6.6 \mathrm{~m}$, in the research area. The maximum thickness of the lignite seam $(13 \mathrm{~m})$ corresponds to 


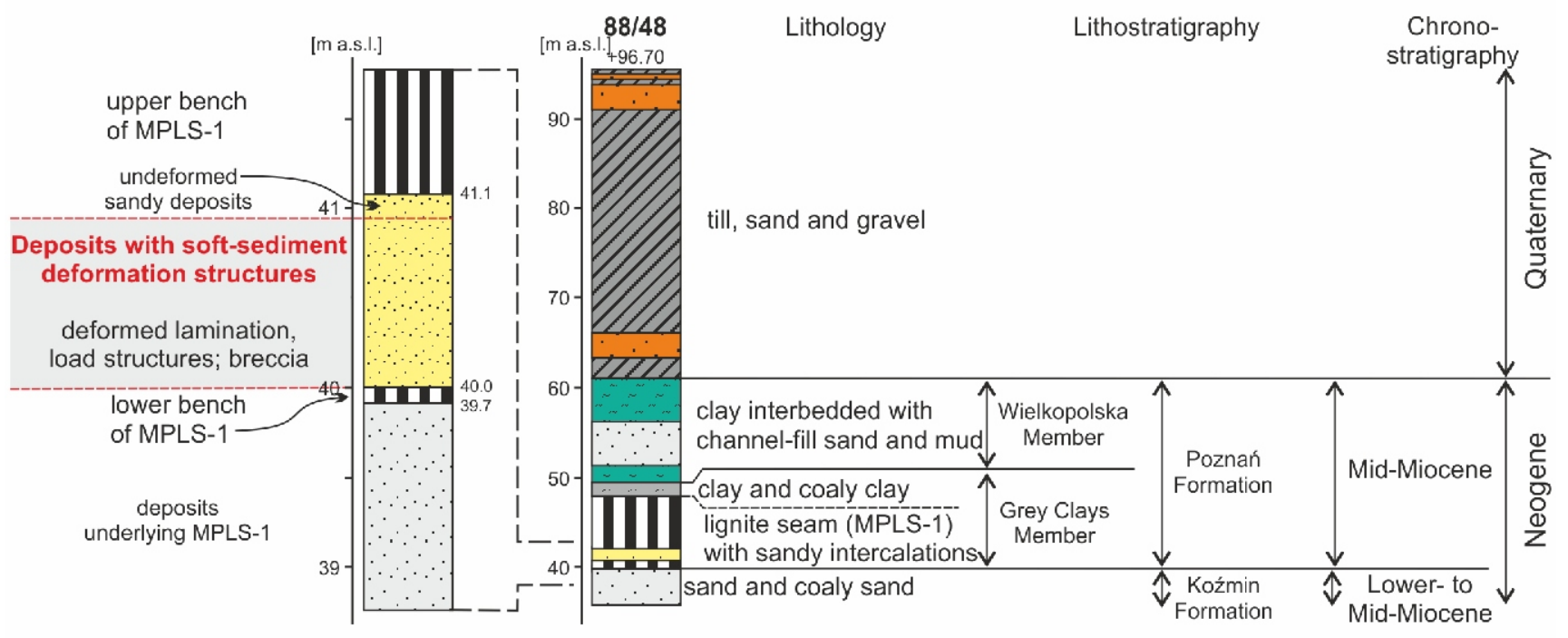

Fig. 2. Key section of the Cenozoic succession in the study area

Note position of the deformed clastic interbeds within the first Mid-Polish lignite seam (MPLS-1), including both ductile and brittle deformation structures; note also that the uppermost layer of the siliciclastic deposits is non-deformed

approx. $26 \mathrm{~m}$ of the original thickness of the peat (Widera, 2015). It was formed in the middle part of the Middle Miocene, at $15 \mathrm{Ma}$ (Kasiński and Słodkowska, 2016; Słodkowska and Kasiński, 2016). MPLS-1, including the siliciclastic interbeds studied, is being exploited in the Jóźwin IIB lignite opencast mine, which belongs to the Konin Lignite Mine. It is currently believed that the accumulation of peat, from which MPLS-1 formed, took place as low-lying mires in the overbank zone of the Middle Miocene fluvial system (Widera, 2016a; Widera et al., 2017a). Clays, characterized by a grey colour, with wood remains (xylites) that belong (together with MPLS-1) to the Grey Clays Member, rest in a few places at the top of MPLS-1 (Fig. 2; Piwocki and Ziembińska-Tworzydło, 1997; Widera, 2007, 2013a; Widera et al., 2017b).

The Neogene ends with the muddy Wielkopolska Member, which overlies the lignite-bearing Grey Clays Member in central Poland (Fig. 2). These predominantly muddy deposits, with sandy channel-fills, are attributed to a Late Neogene anastomosing river system (Widera, 2013a; Widera et al., 2017b). The Wielkopolska Member is up to $20 \mathrm{~m}$ thick in the Jóźwin IIB opencast area (Fig. 2).

The Quaternary cover, mainly consisting of slightly consolidated glaciogenic deposits (till, gravel, sand and mud), caps this geological succession (Fig. 2). It forms a relatively thick and continuous sedimentary body, an average of 40-50 m thick, which is locally glaciotectonically deformed (Widera, 2018). Moreover, the Quaternary deposits have been partially removed by erosive processes of the Pleistocene Scandinavian ice-sheets and their meltwaters (Widera, 2013b, 2014; Widera et al., 2017b).

\section{DATA AND METHODS}

The deformed siliciclastic deposits, splitting MPLS-1, were well exposed between May and September 2018 in the Jóźwin IIB lignite opencast mine (Figs. 1 and 3). At that time, at the lowermost exploitation level, the sedimentological observations presented herein were carried out and 3 representative samples of the deposits investigated were collected for laboratory analysis. The mine walls and dewatering channels were also mapped in places where the siliciclastic deposits were exposed (Fig. 1C, D), and 42 palaeocurrent directions were measured. Furthermore, the outline of the Cenozoic stratigraphy for the study territory was presented on a basis of a key section - borehole no. 88/48 (Fig. 2).

The section examined consists of lower and upper benches of the lignite seam (MPLS-1) that are up to 1 and 7-8 m thick, respectively. These lignites are split by clastic facies, the subject of this research. During fieldwork they formed a lens-shaped sandy body, which was more than $550 \mathrm{~m}$ long and $\sim 1-2 \mathrm{~m}$ thick in a $\mathrm{N}-\mathrm{S}$ direction, while in the $\mathrm{E}-\mathrm{W}$ direction it was wedge-shaped with a thickness decreasing from $\sim 1$ to $0 \mathrm{~m}$ to the west (Fig. 3).

Based on detailed field studies, partly supported by results of laboratory analyses, nine clastic facies and two lignite lithotypes were distinguished. For description of textural and structural features of these clastic facies the letter code of Miall (1977; Table 1) is applied, while for the under- and overlying lignites the codification of lithotypes of Widera (2012, 2016b; Table 1) is used. Sedimentary structures are termed after Collinson and Thompson (1982) and Allen (1982), while terminology of soft-sediment deformation structures is after Dżułyński and Walton (1965) and Allen (1982). Criteria for distinguishing soft-sediment deformation structures caused by earthquakes, are used here as proposed by various researchers (e.g., Sims, 1975; Obermeier and Pond, 1998; Rossetti and Santos, 2003; Obermeier et al., 2005; Moretti and Sabato, 2007; van Loon, 2009; Owen and Moretti, 2011; Owen et al., 2011; Moretti and van Loon, 2014; Moretti et al., 2016).

Representative samples of three macroscopically distinguishable beds were selected for laboratory testing to determine the grain size and organic matter content. These samples were from: the uppermost, non-deformed layer of massive sand - sample A; the brecciated, planar cross-stratified layers of both sands (without organic matter) - sample B; and organic sands sample C, respectively (Fig. 4 and Table 2). In the last case, the organics were burned in an oven at $550^{\circ} \mathrm{C}$. To determine the grain size, the standard sieving method was used. Statistics of the grain-size distribution were computer calculated with a 
Ta ble 1

Codification of fine-grained siliciclastic facies (after Miall, 1977) and lignite lithotypes (after Widera, 2012, 2016b) used in this paper

\begin{tabular}{|c|c|}
\hline Code & Facies \\
\hline Sm & sand with a massive structure \\
\hline $\mathrm{SCm}(\mathrm{d})$ & coaly sand with a massive and deformed structure \\
\hline Sh & sand with a horizontal stratification \\
\hline $\operatorname{Sh}(d)$ & sand with a horizontal and deformed structure \\
\hline $\operatorname{SCh}(d)$ & coaly sand with a horizontal and deformed structure \\
\hline St & sand with a trough cross-stratified structure \\
\hline $\mathrm{Sr}$ & sand with a ripple cross-stratified lamination \\
\hline $\operatorname{Sp}(d)$ & $\begin{array}{c}\text { sand with a planar cross-stratified and deformed } \\
\text { structure }\end{array}$ \\
\hline $\operatorname{SCp}(d)$ & $\begin{array}{l}\text { coaly sand with a planar cross-stratified } \\
\text { and deformed structure }\end{array}$ \\
\hline Code & Lithotypes \\
\hline $\mathrm{DLm}(\mathrm{fr})$ & detritic lignite with a massive and fractured structure \\
\hline XDLm(fr) & $\begin{array}{c}\text { xylodetritic lignite with a massive and fractured } \\
\text { structure }\end{array}$ \\
\hline
\end{tabular}

SIEWCA grain-size program at the Institute of Geology in Poznań, Poland. The results of these calculations, including grain-size statistical parameters and their descriptions, are given in Table 2. Overall, the data obtained were helpful in describing the rheological properties of the deposits examined in terms of their susceptibility to ductile and brittle deformation.

\section{RESULTS}

\section{PETROGRAPHY AND SEDIMENTOLOGY OF THE LIGNITE SEAM}

The first Mid-Polish lignite seam (MPLS-1) consists of two benches that are split by siliciclastic deposits in the study area (Figs. 2-5). These lignite benches comprise two lithotypes with a detritic and xylodetritic texture. They are both characterized by a massive and fractured structure. Because the clastic facies are situated between them, these lithotypes require brief description and interpretation.

Description of lignite lithotypes. The lower bench of MPLS-1 is built of a detritic lignite with a massive and fractured structure - DLm(fr), while the upper bench is made of a xylodetritic lignite with a massive and fractured structure XDLm(fr) (Figs. 4 and 5; Table 1). These two lithotypes include a greater percentage of fine-graded plant detritus $(<1 \mathrm{~cm})$ than do xylites, that is, fossilised wood remains $(>1 \mathrm{~cm})$. The lower lignite division includes $>90 \%$, and the upper division $>50 \%$, of
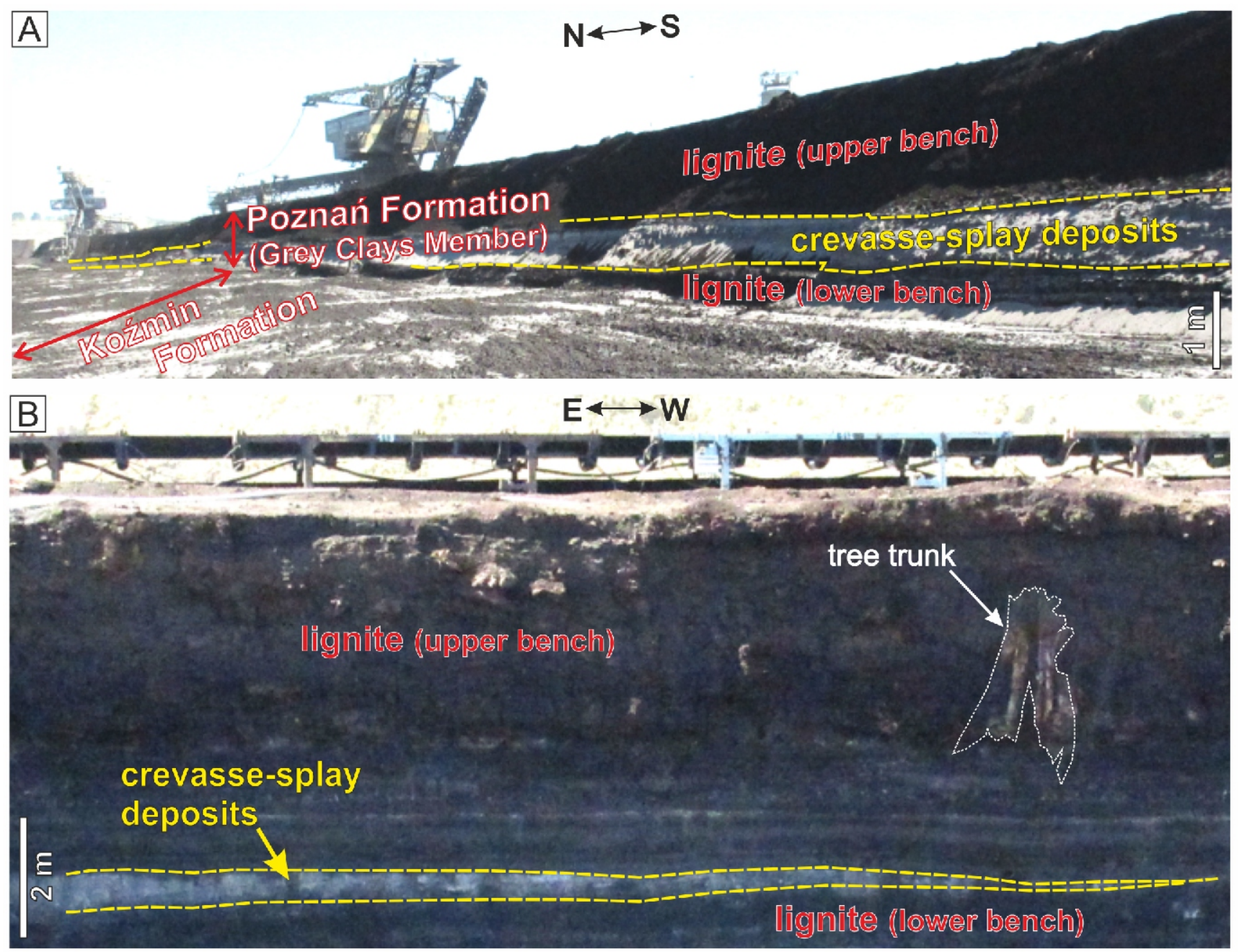

Fig. 3. General view of the examined siliciclastic succession examined, representing the Poznań Formation (Grey Clays Member) of Middle Miocene age, situated between two benches of the lignite seam (MPLS-1) 
Statistical calculations and descriptions of representative samples taken from siliciclastic deposits within MPLS-1, Jóźwin lignite opencast mine in central Poland

\begin{tabular}{|c|c|c|c|c|c|c|}
\hline \multirow{4}{*}{$\begin{array}{l}\text { Median } \\
\text { grain size }\end{array}$} & \multicolumn{6}{|c|}{ Sample } \\
\hline & \multicolumn{2}{|c|}{$A$} & \multicolumn{2}{|r|}{$B$} & \multicolumn{2}{|r|}{$\mathrm{C}$} \\
\hline & $2.330 \mathrm{phi}$ & fing & 2.416 phi & & $1.930 \mathrm{phi}$ & \\
\hline & $0.199 \mathrm{~mm}$ & fine sand & $0.187 \mathrm{~mm}$ & Tine sand & $0.263 \mathrm{~mm}$ & medium sand \\
\hline \multirow{2}{*}{$\begin{array}{l}\text { Mean } \\
\text { grain size }\end{array}$} & 2.364 phi & \multirow{2}{*}{ fine sand } & 2.413 phi & \multirow{2}{*}{ fine sand } & $1.922 \mathrm{phi}$ & \multirow{2}{*}{ medium sand } \\
\hline & $0.194 \mathrm{~mm}$ & & $0.188 \mathrm{~mm}$ & & $0.264 \mathrm{~mm}$ & \\
\hline \multirow{2}{*}{$\begin{array}{l}\text { Standard } \\
\text { deviation }\end{array}$} & 0.466 phi & \multirow{2}{*}{ well-sorted } & $0.328 \mathrm{phi}$ & \multirow{2}{*}{ very well-sorted } & $0.486 \mathrm{phi}$ & \multirow{2}{*}{ well-sorted } \\
\hline & $0.724 \mathrm{~mm}$ & & $0.796 \mathrm{~mm}$ & & $0.714 \mathrm{~mm}$ & \\
\hline Skewness & -0.125 & coarse-skewed & -0.017 & nearly symmetrical & -0.030 & nearly symmetrical \\
\hline Kurtosis & 1.190 & leptokurtic & 1.056 & mesokurtic & 1.061 & mesokurtic \\
\hline
\end{tabular}

For location of sampling sites see Figure 4

fine-detrital matrix (Kwiecińska and Wagner, 1997; Widera, 2012, 2016b).

The exposure studied in the Jóźwin IIB lignite opencast mine also includes a fracture system, comprising two orthogonal sets of open fractures (cleats) that are also perpendicular to the bedding (see Fig. 5A), that are the best formed among all Polish lignite seams. These fracture sets are additionally NW-SE- and NE-SW-striking, that is, parallel and perpendicular to the elongation of the main tectonic structures in central Poland (Widera, 2014).

Interpretation of lignite lithotypes. The origin of the detritic lignite is associated with a fen or open-water environment, while the xylodetritic lignite was formed when bushy vegetation dominated in the mire area (Teichmüller, 1989; Markič and Sachsenhofer, 1997; Ticleanu et al., 1999; Widera, 2012, 2016b). The presence of the clastic facies within MPLS-1, representing crevasse-splay deposits, provides additional evidence for the existence of a low-lying mire. Because this mire was located near the river channel it can therefore be interpreted as a backswamp (e.g., McCabe, 1984; Kirschbaum and McCabe, 1992; Flores, 1993; Diessel et al., 2000; Davies-Vollum and Kraus, 2001; Toonen et al., 2016).

The NW-SE-striking fractures are closely associated with pre-Cenozoic regional tectonic trends. Therefore, the formation of the fractures (cleats) is at least partially linked with tectonic processes that affected MPLS-1 syn- and postdepositionally (Widera, 2014).

\section{SEDIMENTOLOGY OF THE SILICICLASTIC DEPOSITS}

The siliciclastic deposits occurring within MPLS-1 consist predominantly of fine-grained sands that are characterized by a unimodal grain-size distribution. They are interbedded with a slightly coarser fraction (medium sand), which is enriched with organic matter. Moreover, these sands are well to very well sorted, slightly coarse-skewed as well as mesokurtic and leptokurtic (Table 2). In general, they may be divided into two facies associations. The first association encompasses the lower and middle parts, while the second association constitutes the uppermost part of the section examined (Figs. 4 and 5). Within both associations, nine facies have been distinguished (Table 3) representing different environments of the crevasse-splay deposition.
Description of facies association 1 (FA1). Facies association 1 (FA1) represents five facies that are pervasively deformed in plastic and brittle modes. FA1 may be divided into three segments (Fig. 4A). The lower segment is $20-40 \mathrm{~cm}$ thick and comprises sand and coaly sand that were originally subhorizontally stratified. They were postdepositionally disturbed, hence the beds are currently undulated and broken - facies $\mathrm{Sh}$ (d) and SCh(d) (Fig. 4B). The middle segment of FA1 is the thickest, up to $50-90 \mathrm{~cm}$, and its internal structure is best visible. The planar cross-stratified beds differ greatly due to the colour contrast between sands and coaly sands with organic content just exceeding $1 \mathrm{wt} \%$ (Figs. 4A and 5A). The deposits described therefore include only two facies that are also strongly deformed $-\mathrm{Sp}(\mathrm{d})$ and $\mathrm{SCh}(\mathrm{d})$. The lighter beds are in the range of $0.6-6 \mathrm{~cm}$ thick, while the darker ones are $0.1-4 \mathrm{~cm}$ thick. They are all internally laminated. The palaeoflow directions have been measured from these beds. The measured palaeocurrent directions vary from 215 to $285^{\circ}$, with an average value of $253^{\circ}$. The upper segment of FA1 comprises deformed deposits that contain the following 3 facies: SCm(d), Sh(d) and $\mathrm{SCh}(\mathrm{d})$ (Fig. 4A). Their summed thickness is in the range of 10-40 cm. These deposits are mainly massive, though remnants of horizontal stratification may be also observed (Fig. 5A, B).

Interpretation of facies association 1 (FA1). FA1 corresponds to a subaqueous crevasse splay that accumulated in standing water. Near-horizontally lying deposits of the lower and upper segments, and steeply dipping $\left(12-25^{\circ}\right)$ sediments of the middle segment are characteristic of bottomset, topset and foreset beds, respectively (Fig. 4A and Table 3). Especially well formed are the so-called 'prograding splay deposits', allowing this form to be called a crevasse-splay microdelta (Teisseyre, 1985; Bristow et al., 1999; Michaelsen et al., 2000; Spicer et al., 2002; Ciarcia and Vitale, 2013; Zieliński, 2014). It is worth noting here that fluvio-deltaic deposition in the overbank zone, including the backswamp areas, is quite common and well documented from both modern and ancient sedimentary successions (e.g., Smith et al., 1989; Tye and Coleman, 1989; Pérez-Arlucea and Smith, 1999; Opluštil, 2005; Rajchl and Uličný, 2005; Rajchl et al., 2008; Bos et al., 2009; Cahoon et al., 2011; Mach et al., 2013; Toonen et al., 2016). Finally, it must be stated that the large-scale foreset beds measured indicate a generally unimodal WSW palaeotransport direction in the SW part of the area under study (see Figs. 1C, D and 3). 

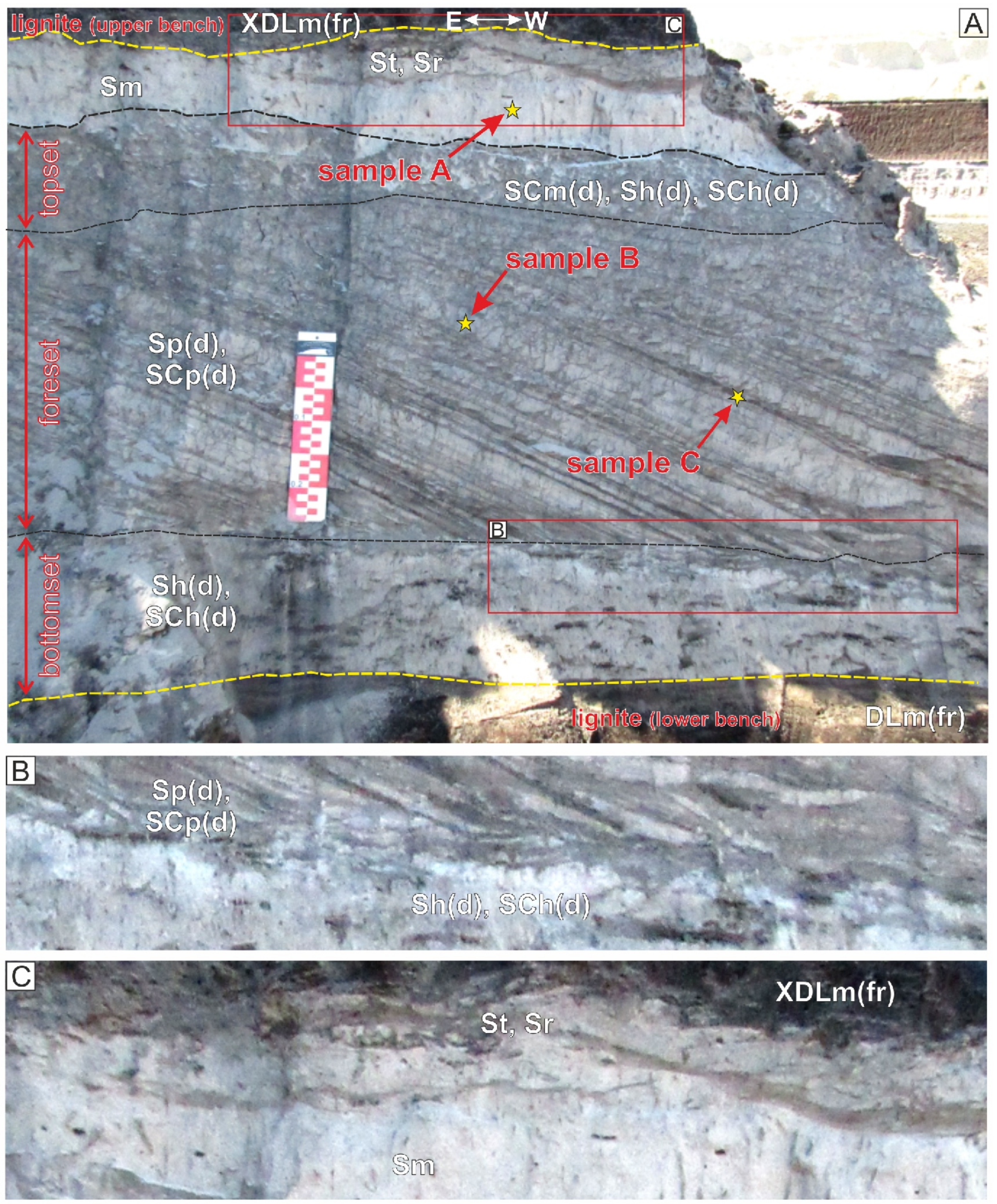

Fig. 4. Representative section of the siliciclastic deposits studied with the lower and upper benches of the lignite seam (MPLS-1) at the base and top, respectively

A - general view of the deposits representing the crevasse-splay microdelta; note position of sampling and facies from which they were collected; B - close-up view of the transition between the foreset and bottomset laminae; note clearly inclined layers in the foreset and almost horizontally lying, slightly disturbed layers in the bottomset; C - close-up view of the uppermost undeformed deposits with remains of trough and ripple cross-lamination; note the widespread massive structure in the non-deformed sediments; for explanations of the facies and lithotype codes see Table 1 

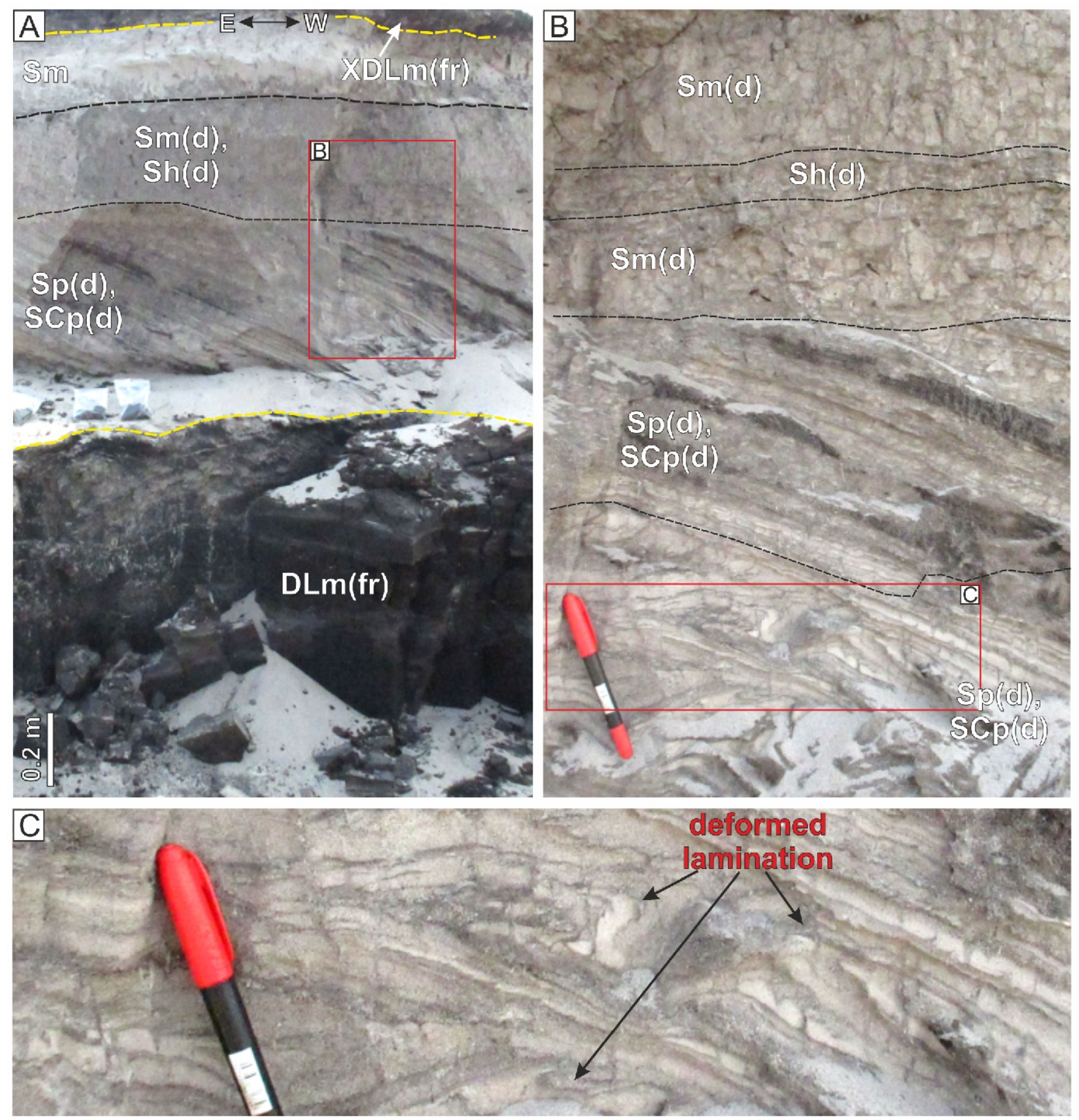

Fig. 5. Seismically-induced deformation structures in the lower and middle parts of the siliciclastic deposits

A - general view of the section; B - commonly brecciated deposits with additional plastic deformation structures only in their lowermost part; $\mathbf{C}$ - close-up view of the deformed lamination in form of asymmetrical folds; note that the plastically deformed deposits are also brecciated; the pen is $14 \mathrm{~cm}$ long 
General sedimentological characteristics of the siliciclastic facies identified within MPLS-1, Jóźwin lignite opencast mine in central Poland

\begin{tabular}{|c|c|c|c|c|}
\hline Facies associations & Facies & Description & Interpretation & $\begin{array}{l}\text { Depositional } \\
\text { environment }\end{array}$ \\
\hline \multirow{3}{*}{$\begin{array}{l}\text { Deformed sands and } \\
\text { coaly sands } \\
\text { (FA1) }\end{array}$} & $\begin{array}{l}\text { Sh(d), } \\
\text { SCh(d) }\end{array}$ & $\begin{array}{l}\text { Fine-grained sand and coaly (carbonaceous) } \\
\text { sand stratified horizontally, deformed plastic- } \\
\text { ally and brecciated; up to } 40 \mathrm{~cm} \text { thick; under- } \\
\text { lain by lower bench of lignite seam (MPLS-1) }\end{array}$ & $\begin{array}{l}\text { Bottomset beds deposited along } \\
\text { the bottom of standing water, i.e. } \\
\text { pond or lake, existing in the } \\
\text { backswamp area; lower segment } \\
\text { of the crevasse-splay microdelta; } \\
\text { overlain by foreset beds }\end{array}$ & \multirow{3}{*}{$\begin{array}{l}\text { Subaqueous } \\
\text { crevasse splay, } \\
\text { i.e. cre- } \\
\text { vasse-splay } \\
\text { microdelta }\end{array}$} \\
\hline & $\begin{array}{l}\operatorname{Sp}(d) \\
S C p(d)\end{array}$ & $\begin{array}{c}\text { Fine- to medium-grained sand and coaly } \\
\text { (carbonaceous) sand with a planar } \\
\text { cross-stratification; deformed plastically and } \\
\text { brecciated in the lowermost part; completely } \\
\text { brecciated in the middle and upper part; up } \\
\text { to } 50-90 \mathrm{~cm} \text { thick; beds are inclined at an } \\
\text { angle of } 12-25^{\circ}\end{array}$ & $\begin{array}{l}\text { Foreset beds accumulated on a } \\
\text { sloping surface along the delta } \\
\text { front; middle segment of the cre- } \\
\text { vasse-splay microdelta front; un- } \\
\text { derlain by bottomset beds and } \\
\text { overlain by topset beds }\end{array}$ & \\
\hline & $\begin{array}{l}\operatorname{SCm}(d) \\
\operatorname{Sh}(d) \\
\operatorname{SCh}(d)\end{array}$ & $\begin{array}{c}\text { Sand and coaly (carbonaceous) sand with a } \\
\text { massive structure or poorly visible horizontal } \\
\text { stratification; all lithofacies fully brecciated; } \\
\text { up to } 50 \mathrm{~cm} \text { thick }\end{array}$ & $\begin{array}{c}\text { Topset beds deposited above wa- } \\
\text { ter level in pond or lake existed in } \\
\text { the backswamp area; upper seg- } \\
\text { ment of the crevasse-splay } \\
\text { microdelta }\end{array}$ & \\
\hline $\begin{array}{l}\text { Undeformed sands } \\
\text { and coaly sands } \\
\text { (FA2) }\end{array}$ & $\begin{array}{l}\text { Sm, Sh, } \\
\text { St, Sr }\end{array}$ & $\begin{array}{l}\text { Fine-grained sand predominantly with a mas- } \\
\text { sive structure, sometimes with remains of } \\
\text { trough and ripple cross-stratification or hori- } \\
\text { zontal bedding; no traces of deformations; } \\
\text { only up to } 30 \mathrm{~cm} \text { thick; overlain by upper } \\
\text { bench of lignite seam (MPLS-1) }\end{array}$ & $\begin{array}{l}\text { Alluvial fen accumulated at the top } \\
\text { of the older crevasse-splay } \\
\text { microdelta deposits in the } \\
\text { overbank (backswamp) area; no } \\
\text { ponds or lakes in the backswamp } \\
\text { area; FA2 covers FA1 }\end{array}$ & $\begin{array}{l}\text { Subaerial cre- } \\
\text { vasse splay }\end{array}$ \\
\hline
\end{tabular}

For explanations of facies codification see Table 1

Description of facies association 2 (FA2). Facies association 2 (FA2) is uppermost in the siliciclastic succession examined. FA2 is predominantly massive and $10-30 \mathrm{~cm}$ thick (Figs. 4A and 5A), although remnants of horizontal and most often trough and ripple cross-stratification locally occur (Fig. 4C). Thus, this association consists of 4 facies: $\mathrm{Sm}$, Sh, St and Sr. Furthermore, FA2 is characterized by a nearly white colour and the presence of small, fossilised rootlets (Fig. 4A, C).

Interpretation of facies association 2 (FA2). In contrast to FA1, non-deformed deposits of FA2 are assigned in this study to a subaerial crevasse splay due to the lack of "prograding splay deposits' that are typical of accumulation in standing water (e.g., Horne et al., 1978; Teisseyre, 1985; Bristow et al. 1999; Michaelsen et al., 2000; Gębica and Sokołowski, 2001; Zieliński, 2014). In the case of these poorly stratified deposits, it can be presumed that initially they were stratified (sub)horizontally in the lower part with locally occurring layers of ripple and trough cross-stratification in the upper part of FA2. Thus, the barely visible facies Sh shows that sedimentation took place over the entire depositional surface as unconfined sheet flow (e.g., Fielding, 1986; Farrell, 2001). By contrast, the minor facies St and $\mathrm{Sr}$ indicate tractional deposition, related to the movement of ripples and small dunes, on the top surface of the crevasse splay (e.g., Collinson and Thompson, 1982; Bristow et al., 1999; Zieliński, 2014; Widera et al., 2016a). However, the common massive structure of FA2 (facies Sm) may be caused by both good sorting of sediments (Table 2 ) and the destructive role of the rootlets of the vegetation from which the upper lignite bench of MPLS-1 was formed. In the latter case, bioturbation may even lead to complete destruction of the original stratification (van Loon, 2009; Widera et al., 2017a).

\section{SOFT-SEDIMENT DEFORMATION STRUCTURES}

Soft-sediment deformation structures (SSDS) involve the crevasse-splay microdelta unit. However, plastically disturbed structures are present only in the lowest portion, while brittle deformation seems to be ubiquitous, involving the entire sandy body. The first group of ductile deformations consists of deformed laminations, load casts and flame structures (Figs. 5 and 6). Consequently, the second group of brittle deformations comprises only the breccia (Figs. 4-9).

Description of deformed lamination. Deformed lamination occurs in beds representing the bottomset and the lowest 20-30 cm of the foreset. They are best seen among the foreset laminae where they are formed as straight and asymmetrical folds (Figs. 5B, $\mathrm{C}$ and $6 \mathrm{C}$ ). These folds range in height from 3-7 cm and are between 5-10 cm in width. In general, the deformed sets of beds are bounded by non-deformed ones that are also made up of interfingering sands (pale beds) and organic sands (dark beds). The folded sediments are additionally broken, that is, brecciated. In this case, it is significant that the failures (fractures) are arranged subvertically (Figs. 5C and 6C).

Interpretation of deformed lamination. The formation of the deformed lamination involves a plastic state of waterlogged sediments. This is related to partial liquefaction of disturbed layers with different competences for continuous deformation structures (Allen, 1982). In the case of the deposits examined, the sandy beds are competent, while the coaly sand (approx. $1 \mathrm{wt} \%$ of organics) is incompetent as regards folding. Obviously, the process of inter-layer folding indicates compressional conditions that can be caused by groundwater flow pressure (from the river channel to the backswamp area) or by gravity-driven slumps (e.g., Alsop et al., 2017). At least a partial impact of the horizontal component of downward movement, consistent with the slope of the layers, is clearly observable in the basal foreset segment of the crevasse-splay microdelta. This is best seen in the asymmetry of some folds creating the deformed lamination (see Fig. 5B, C).

Description of load structures. Load casts occur in the siliciclastic deposits studied separately, or are associated with flame structures (Fig. 6A, B). They are located only in deposits 

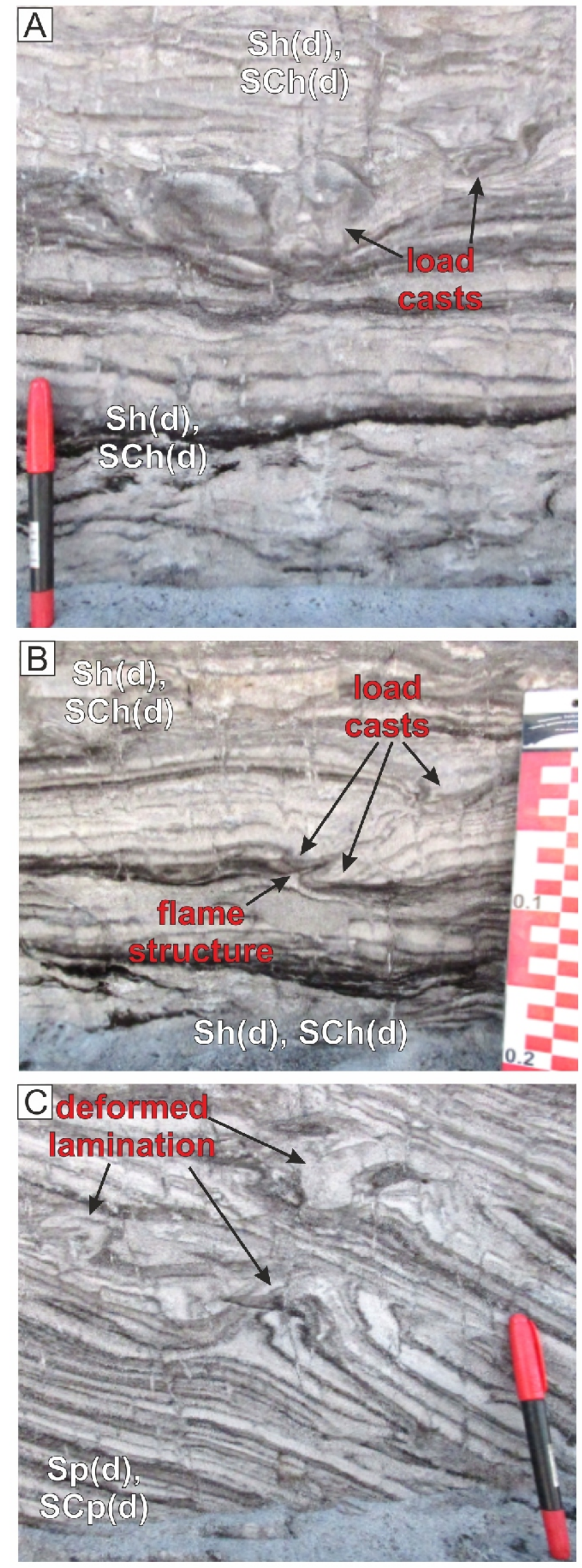
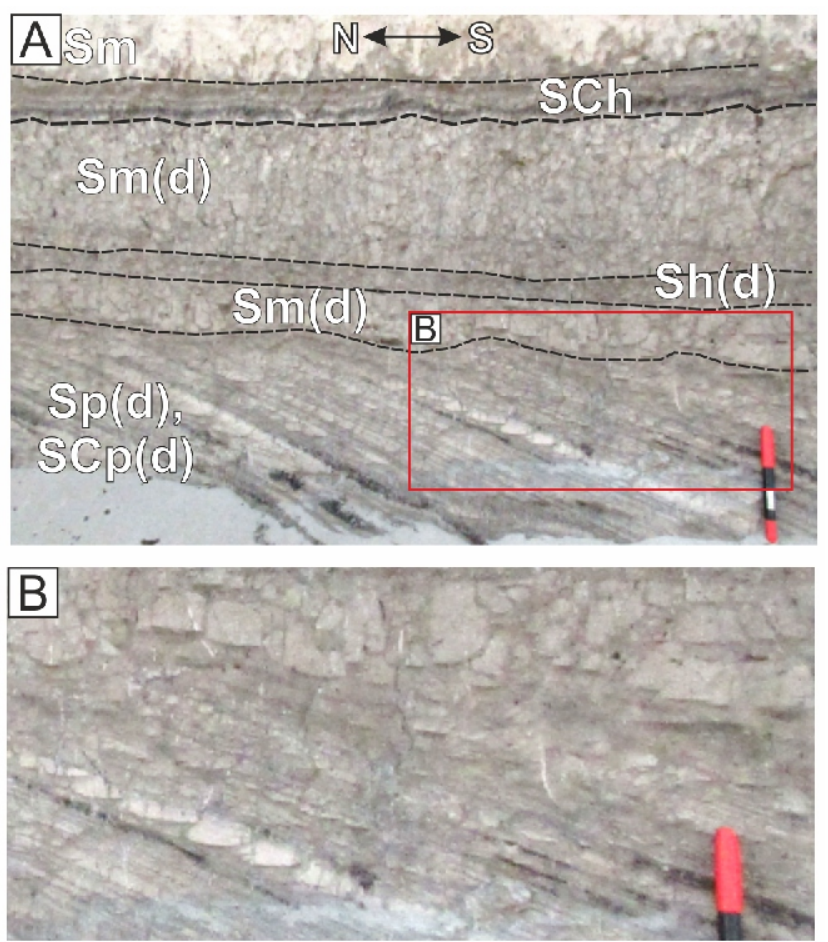

Fig. 7. Brittle deformation structures in the in the middle and upper parts of the crevasse-splay microdelta deposits

A - brecciated deposits capped by non-deformed ones; B close-up view of the pervasively brecciated sediments; note chaotically arranged clasts in the upper part of the photograph and clasts arranged in an orderly manner in the lower part of the photograph; the pen is $14 \mathrm{~cm}$ long

representing the bottomset and lowermost foreset beds. In the case of the individual load casts, their observed width is in the range of $8-20 \mathrm{~cm}$, while their height is up to $12 \mathrm{~cm}$. Furthermore, the under- and overlying layers are slightly undulated. This type of ductile deformation is characterized by partial homogenisation, that is, the internal lamination is invisible and is surrounded by irregularly disturbed laminae (Fig. 6A). In contrast, the load casts accompanying the flame structures are smaller and they have original lamination preserved, albeit disturbed. These flame structures look like pointed tongues of coaly sand piercing the overlying layers of sand. Some of these structures are inclined (Fig. 6B).

Interpretation of load structures. Both load casts and flame structures are the result of rheological differences between adjacent, superimposed beds as seen from their liquefaction features (Dżułyński and Walton, 1965; Collinson and Thompson, 1982). They are generally formed due to unstable density gradients (Anketell et al., 1970) or unequal loading (Allen, 1982). The liquefaction effects of interbedded sediments

Fig. 6. Examples of ductile deformation structures in the lowermost parts of the crevasse-splay microdelta deposits

A - load casts with homogenized internal structure in the bottomset laminae; $\mathbf{B}$ - flame and accompanying load casts in the bottomset laminae; C - deformed lamination in the lowermost part of the foreset laminae; note almost plane-parallel laminated deposits that under- and overlie the deformation structures; the pen is $14 \mathrm{~cm}$ long 

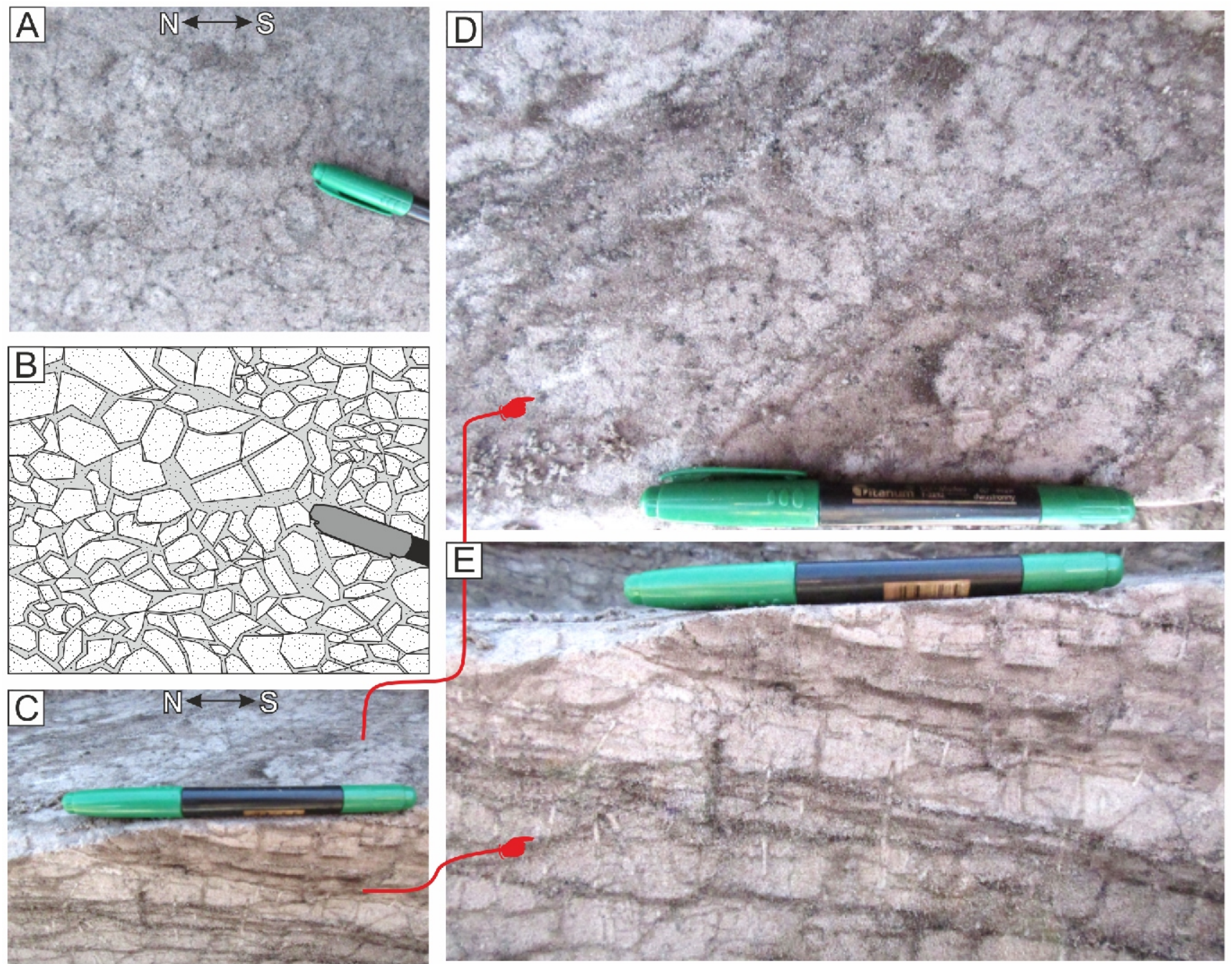

Fig. 8. Breccia studied seen in cross-section and in plan view

A, B - the chaotic breccia in plan view and its interpretive sketch; C-E - the orderly arranged breccia in plan view (D) and in cross-section $(E)$, respectively; the pen cap is $5 \mathrm{~cm}$ long, while the pen is $14 \mathrm{~cm}$ long

with diverse rheological properties, resulting from the shaking of the deposits, have been reproduced experimentally (e.g., Anketell et al., 1970; Owen, 1996; Moretti et al., 1999). In the case of the deposits examined, the coaly sands, which are enriched in organic matter, are more (hydro)plastic. Therefore, sandy beds are immersed in more plastic coaly-sandy beds, or these coaly sands inject into the overlying sands (Fig. 6A, B).

Description of breccia. The brecciation of the deposits studied, representing a crevasse-splay microdelta, is the most characteristic and common feature (Figs. 4-9). Both deposits were previously plastically deformed (Figs. 5 and 6) and those that preserved their original stratification are clearly brecciated (Figs. 7-9). This breccia is matrix-supported in the lower and upper parts (bottomset and topset beds) and clast-supported in the middle part (foreset beds) of the succession examined. In the former case, the breccia is arranged chaotically, while in the latter case it is orderly. This is especially well visible in plan view (Fig. 8A, B, D). Based on laboratory analyses, the brecciated deposits consist of white inorganic sandy clasts, while a grey to black matrix of coaly sands contains slightly more than $1 \mathrm{wt} . \%$ organic matter. The size of the individual sandy clasts is
$0.5-6 \mathrm{~cm}$ (averaging $3 \mathrm{~cm}$ ) long and $0.2-5 \mathrm{~cm}$ (averaging $1.5 \mathrm{~cm}$ ) thick (Figs. 8 and 9).

The chaotically arranged breccia, corresponding to the bottomset and topset beds, is characterized by the presence of steeply dipping fractures and microfaults with vertical displacements of up to $1 \mathrm{~cm}$ (Fig. 9A, B). By contrast, the orderly arranged breccia in the foreset beds is slightly rotated along the inclined stratification. This is the case when the layer of inorganic sand is underlain by a relatively thick, organic-enriched, layer of carbonaceous sand. The sandy clasts here form 'domino-type' deformation structures (Fig. 9C). Finally, the initial failures of the deposits examined can also be observed. These failures (cracks, fractures) are set subvertically and open both upwards and downwards (Fig. 9D).

Interpretation of breccia. The breccia described above was originally composed of interbedded heterolithic deposits that differed significantly in terms of their rheological properties. However, their rheological anisotropy and susceptibility to the brecciation did not play a major role, as both layers of organic and inorganic sands are strongly and equally brecciated (Figs. 4-9). The only exception here is where the deformed clasts of inorganic sands display domino-style geometry 

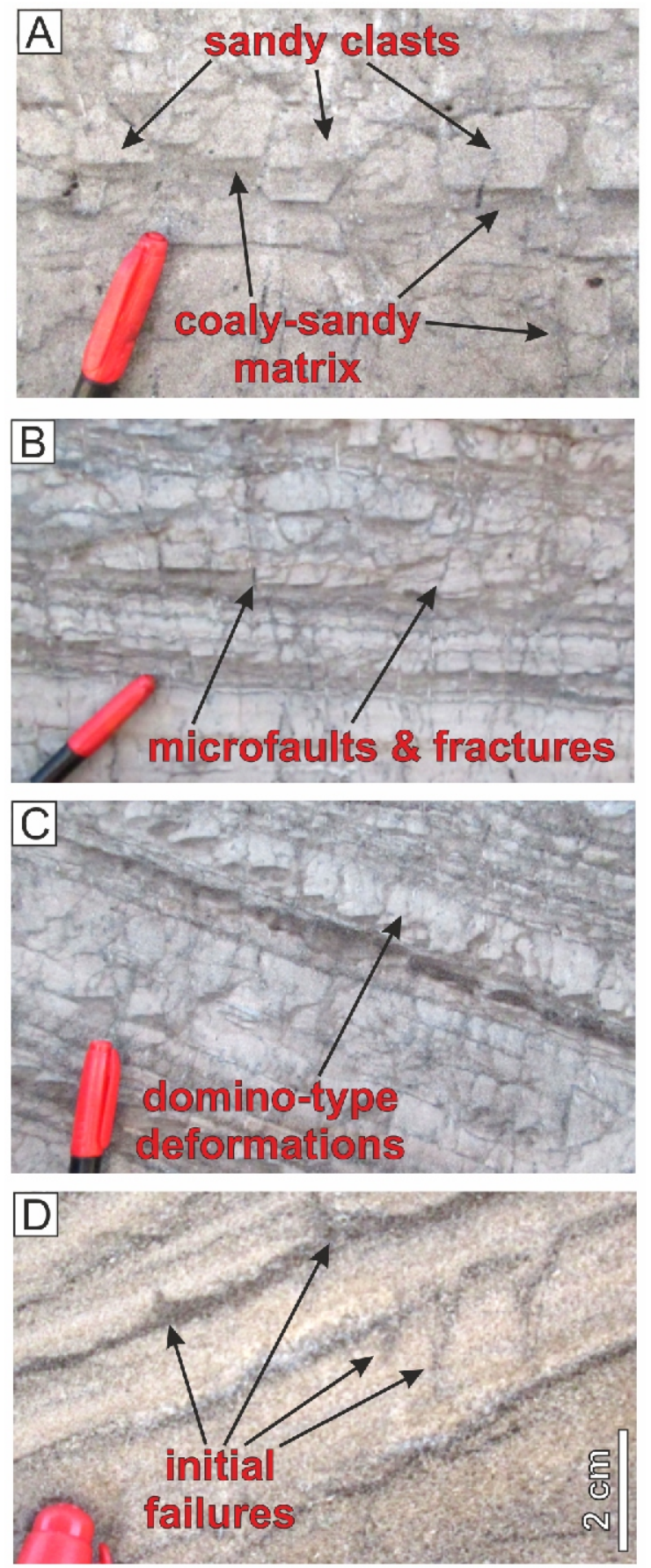

Fig. 9. Examples of brittle deformation structures in the crevasse-splay microdelta deposits

A - sharp-edged and displaced sandy clasts surrounded by a coaly-sandy matrix; B - subvertically arranged fractures and microfaults with vertical offset of up to $1 \mathrm{~cm}$; $\mathbf{C}$ - domino-type brecciation of inclined sandy bed resting above the organic-rich sandy layer; D - initial failures of brecciated deposits indicating their cracking both upwards and downwards

(Fig. 9C). In this case, the layer of underlying organic-rich sands of more plastic behaviour, constitutes the detachment surface along which the slight downslope movement and rotation (in the opposite direction to the dip of the beds) of more competent sandy clasts has occurred (e.g., Basilone et al., 2016; Törő and Pratt, 2016).
The brittle formation, that is, brecciation, took place after these ductile structures were formed. This is clear, as the brittle structures are superimposed on plastic ones (see Figs. 5 and 6 ). Thus, at least two deformation events involved partly the same deposits, that is, the lowermost portion of the microdelta. Furthermore, brecciation of the deposits representing the crevasse-splay microdelta - FA1 - occurred prior to deposition of the overlying sediments related herein to the subaerial crevasse splay - FA2 - which were not deformed (see Figs. 4-6). The formation of the breccia is attributed to hydraulic fracturing driven by high pore-water pressure in the liquefied deposits. Brittle deformation of non-lithified sediments requires much stronger seismic shaking than is needed for the formation of plastic deformation structures (Obermeier and Pond, 1998; Obermeier et al., 2005). Therefore, the question arises of whether there has been a sudden increase in pore-water pressure, resulting in fractures and microfaults (Fig. 9A, B).

In this paper, the origin of the breccia linked with synsedimentary tectonics (sensu lato) that affected the study area in the Middle Miocene. Other geological facts that support this point of view (discussed below) are taken into account in this interpretation. Moreover, the lack of non-seismic trigger mechanisms that can produce similar breccias, such as overloading, storm waves, permafrost, and so on, may be indirect evidence of a tectonic origin (Rossetti and Santos, 2003; Moretti and Sabato, 2007; Owen and Moretti, 2011; Owen et al., 2011; Moretti and van Loon, 2014; Moretti et al., 2016). Thus, one possible explanation for the dramatic growth in pore-water pressure is an abrupt change in the groundwater level, caused by strong earthquakes, in the backswamp area. Pore-water pressure can also increase by changing the grain packing during seismically-induced liquefaction, when water can be expelled (Obermeier and Pond, 1998). In such conditions, the water flows upwards, piercing the overlying beds or lifting and bending them. As a result, the initial failures were first created, which are directed both upwards and downwards (see Fig. 9D). Finally, all the crevasse-splay microdelta sediments were layer-by-layer deformed in the form of the interpreted seismic breccia.

\section{DISCUSSION}

Issues related to the deposition and deformation of the siliciclastic sediments, which split the first Mid-Polish lignite seam (MPLS-1) in central Poland, are first explained and discussed in terms of the conceptual model of deposition and deformation for the formation of the two crevasse splays, followed by discussion of the criteria, by means of which the deformation structures studied may be linked with tectonics.

\section{MODEL OF DEPOSITION AND DEFORMATION}

We propose a conceptual model that graphically illustrates the formation of both associations of siliciclastic facies and their deformation structures (Fig. 10). This is shown in four stages, the first and fourth of which relate to the deposition of the strongly deformed sediments of the crevasse-splay microdelta - FA1 and non-deformed deposits of the crevasse-splay - FA2 (Fig. 10A, F). However, the other two stages refer to the environmental conditions necessary for the formation of ductile and brittle deformation structures, respectively (Fig. 10B-E).

At the first stage, when the lower bench of MPLS-1 accumulated, shallow lakes and ponds were present in the mire (backswamp) area (Fig. 10A). These were located close to the 

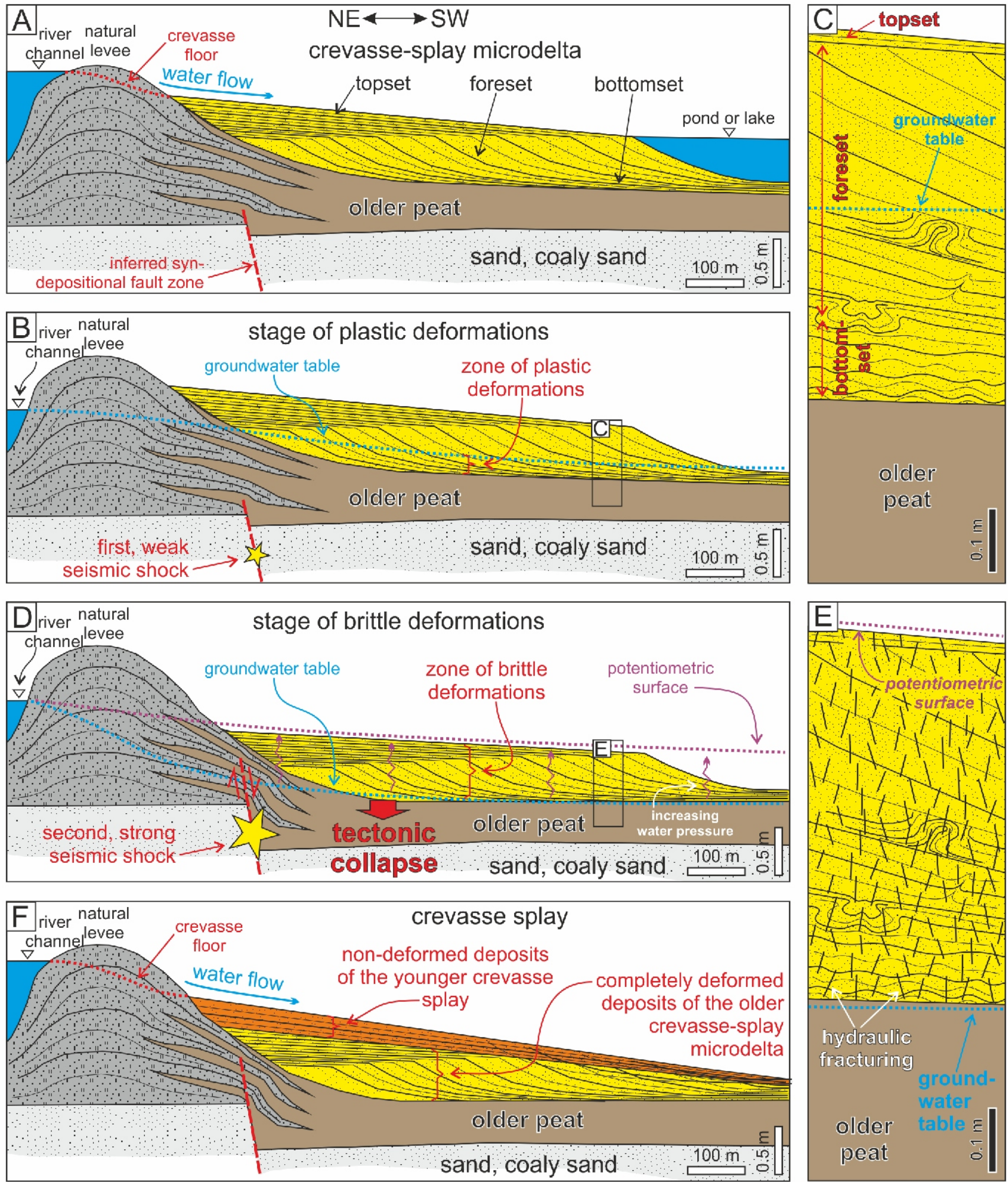

Fig. 10. Conceptual model showing deposition and soft-sediment deformation of the siliciclastic deposits interbedded with the first Middle Miocene lignite seam (MPLS-1) in the Jóźwin IIB opencast mine in central Poland

A - initial stage, the crevasse-splay microdelta formation in the backswamp area; B - ductile deformation structures of water-saturated deposits caused by weak seismic shaking; C - close-up view of the plastically deformed deposits shown in Figure 10B; compare with Figures 5 and 6; $\mathbf{D}$ - brittle deformation structures in conditions of increasing water pressure caused by strong seismic shocks and small-scale collapse; $\mathbf{E}$ - close-up view of the brittle-deformed deposits shown in Figure 10D; compare with Figures 5, 6 and 9; $\mathbf{F}$ - accumulation of non-deformed crevasse-splay deposits in a subaerial backswamp environment 
river channel, which water sourced the water that breached the natural levee and flooded the backswamp. At that time the crevasse splay was formed that extended to this reservoir of standing water. This is how the so-called 'prograding splay deposits' were formed that are characteristic of a crevasse-splay microdelta (Fig. 10A; Teisseyre, 1985; Bristow et al., 1999; Michaelsen et al., 2000; Spicer et al., 2002; Ciarcia and Vitale, 2013; Zieliński, 2014).

Afterwards, the groundwater table was lowered to cover only only the bottomset and lowermost $20-30 \mathrm{~cm}$ of the foreset beds (Fig. 10B). In such conditions liquefaction of the sandy deposits below the groundwater table took place. As a result, plastic deformation structures (deformed lamination, load and flame structures) arose in the lower parts of the crevasse-splay microdelta (Fig. 10B, C).

Brittle deformation structures probably could have arisen during a modest, but relatively widespread tectonic collapse of the microdelta succession. Shortly after that, the groundwater table was lower, while the potentiometric surface was located higher (Fig. 10D). This situation could cause a sudden rise in pore-water pressure and force water upwards. The change of grain packing could additionally increase the pore pressure and consequently the extent of the hydraulic fracturing (Obermeier and Pond, 1998; Obermeier et al., 2005). Thus, the entire succession of the crevasse-splay microdelta is pervasively brecciated, especially deposits representing the foreset beds (Fig. 10D, E).

The last stage distinguished is basically a repetition of the first stage. However, in this case, the crevasse splay was deposited subaerially as seen from the lack of "prograding splay deposits". Among these deposits plastic and brittle deformations do not occur, and so they were not disturbed tectonically (Fig. 10F).

\section{IDENTIFICATION OF SEISMIC DEFORMATION STRUCTURES}

As recommended by Owen et al. (2011), correct recognition of seismically-induced deformation structures (seismites) requires a three-step approach. First, a facies analysis must be carried out, as completed above. Then the mechanisms of deformation should be provided, which is also presented above. Finally, the criteria for identifying these deformation structures should be discussed as below (Owen et al., 2011). Thus, over the past few decades, many researchers have proposed diagnostic criteria for the differentiation between seismic and non-seismic deformations of unconsolidated sediments (e.g., Sims, 1975; Rossetti and Santos 2003; Obermeier et al., 2005; Moretti and Sabato, 2007; van Loon, 2009; Owen and Moretti, 2011; Owen et al., 2011; Moretti and van Loon, 2014; Moretti et al., 2016 and references therein). The most important of these criteria are as follows: (1) large areal extent and lateral continuity; (2) occurrence in a tectonically active area; (3) similarity to other earthquake-induced deformations; and (4) lack of nonseismic mechanisms of deformation formation.

The first criterion has been met in this case. The area studied is more than $0.1 \mathrm{~km}^{2}$, while the total length of mine walls (including dewatering channels subjected to detailed observations and mapping) exceeded $1 \mathrm{~km}$ (see Fig. 1C, D). Thus, the entire succession of the crevasse-splay microdelta is strongly deformed. For the second criterion, it is possible to indicate some supporting data. Thus, there are faults occurring in strata underlying MPLS-1, within the lignite seam as well as crossing MPLS-1 (Widera, 2007, 2013b, 2016c). The fracture sets (cleats) within MPLS-1, documented a few hundred metres west of the siliciclastic deposits studied, in part indicate tectonic activity (Widera, 2014). Hence, the area of the Jóźwin IIB lignite opencast mine was active syn- and postdepositionally. In other words, the area under study was strongly affected tectonically when MPLS-1, including the siliciclastic interbeds, accumulated in the Middle Miocene. The soft-sediment deformation structures identified in the field and characterized in this paper are morphologically similar to structures from areas that were undoubtedly subject to seismic shocks, that is, syndepositional tectonics (e.g., Dżułyński and Walton, 1965; van Loon et al., 1995; Gruszka and Zieliński, 1996; Rossetti and Santos 2003 Gruszka and van Loon, 2007; Moretti and Sabato, 2007; Widera and Hałuszczak, 2011; Basilone et al., 2016; Törő and Pratt, 2016; etc.). Some of these deformational structures induced by seismically triggered liquefaction (or fluidisation) have been modelled in the laboratory using, for example, a shaking table (e.g., Owen, 1996; Moretti et al., 1999).

Nevertheless, other possible non-seismic trigger mechanisms leading to liquefaction (and/or fluidisation) must also be considered. Firstly, sudden changes in the water-table level can produce such SSDSs as sand boils and dikes (e.g., Holzer and Clark, 1993). However, these are morphologically different from the load casts and flame structures described in this paper (see Figs. 5 and 6). Ductile deformation structures within in the foreset laminae, as in the case of migrating tidal dunes (Chiarella et al., 2016), can be formed by the sudden deposition or overloading. Such an interpretation is possible, although it only partiy explains the origin of the deformation structures studied. It is worth noting that plastically disturbed layers of the crevasse-splay microdelta involve the bottomsets and lower portion of the foresets (see Fig. 5). In contrast, load structures are present along the entire foreset units (and dominate the upper parts) of tidal dunes (cf. Chiarella et al., 2016: fig. 12). Due to the relatively shallow occurrence of the Cretaceous bedrock, mainly built of limy sandstones and marls, the process of karstification must also be considered in the creation of SSDSs. In this case, deformation structures would follow the collapse with its characteristic features, that is, a conical shape, and large-scale and vertically elongated deformational structures (e.g., Moretti et al., 2011). So far, no caverns have been found in the Jóźwin IIB opencast area, that may be evidence of dissolution of carbonate rocks in the bedrock, and the morphology of the SSDSs investigated is drastically different from those typical of karst-induced collapse.

Hence, all the deformation structures examined in this paper, both ductile and brittle, may be interpreted as seismites (Seilacher, 1969), including the seismic breccia (Shukla and Sharma, 2018). Current knowledge of the geological setting together with field observations preclude other factors (changes in the height of the water table, sudden deposition, overloading, karst, etc.).

\section{CONCLUSIONS}

This paper describes deposits of crevasse splays, including of a crevasse-splay microdelta, which split the first Middle Miocene lignite seam (MPLS-1) in central Poland. The studies consider both the sedimentological characteristics of the siliciclastic facies and the structural characteristics of the deformation structures. The major conclusions of the research can be summarized as follows:

1. Currently exploited in the Jóźwin IIB opencast (Konin Lignite Mine, central Poland), the lignite seam, MPLS-1, of Middle Miocene age, is interbedded with weakly compacted siliciclastic deposits. These were interpreted as two superimposed crevasse splays and two facies associations FA1 and FA2, corresponding to these splays, were distinguished. In addition, FA1 
is strongly deformed, while FA2 shows no traces of deformation.

2. The lower FA1 accumulated in standing water (a lake or pond) in a backswamp area during the formation of MPLS-1. The presence of three segments, representing bottomset, foreset and topset, is typical of a delta. Because it is relatively small and is genetically associated with a crevasse splay, it is interpreted as a crevasse-splay microdelta. In contrast, the upper FA2 was deposited subaerially as a thinner, one-segment body, a "prograding splay deposit".

3. Only the crevasse-splay microdelta deposits are strongly disturbed, with both plastic and brittle deformation. Plastic deformation structures (deformed lamination, load casts and flame structures) were formed first, while brittle deformation (breccia) took place later being imposed on previous structures. Both types of deformation were most likely generated by seismic shocks (earthquakes) that caused liquefaction of the deposits, resulting in (hydro)plastic disturbances or hydraulic fracturing, that is, brecciation. The organic matter content (more than $1 \mathrm{wt} . \%$ ) likely played a significant role in the rheological properties of sediments of very similar grain size. Thus, the coaly sands could have deformed more plastically than the inor- ganic sands that are much more competent and could have resulted in brittle deformation.

4. The deformation structures investigated meet the most important criteria for earthquake-induced structures as suggested by other researchers, and other mechanisms of their formation cannot be convincingly pointed to. Therefore, they can be considered as seismites. Finally, the crevasse-splay microdelta from the Jóźwin IIB opencast in central Poland, sediments of which are partly plastically deformed and pervasively brecciated, is the first documented such deposit in all the Polish lignite-bearing areas.

Acknowledgements. We would like to thank M. Dziamara from the Geological Department of the Konin Lignite Mine for his logistical support. The authors are deeply grateful to J.R. Kasiński (Polish Geological Institute - National Research Institute, Warsaw, Poland) and M. Moretti (University of Bari, Italy) for their evaluation of the typescript. In addition, many thanks are extended to A. Wysocka (University of Warsaw, Poland), the Co-Editor of the Geological Quarterly, for her editorial handling. This paper is supported by the National Science Centre, Poland, through research project no. 2017/27/B/ST10/00001 (to MW).

\section{REFERENCES}

Alsop, G.I., Marco, S., Levi, T., Weinberger, R., 2017. Fold and thrust systems in Mass Transport Deposits. Journal of Structural Geology, 94: 98-115.

Allen, J.R.L., 1982. Sedimentary Structures: Their Character and Physical Basis. Vol. II. Elsevier, New York.

Anketell, J.M., Cegła, J., Dżułyński, S., 1970. On the deformational structures in systems with reversed density gradients. Annales Societatis Geologorum Poloniae, 40: 3-30.

Basilone, L., Sulli, A., Morticelli, M.G., 2016. The relationships between soft-sediment deformation structures and synsedimentary extensional tectonics in Upper Triassic deep-water carbonate succession (Southern Tethyan rifted continental margin - Central Sicily). Sedimentary Geology, 344: 310-322.

Bos, I.J., Feiken, H., Bunnik, F., Schokker, J., 2009. Influence of organics and clastic lake fills on distributary channel processes in the distal Rhine-Meuse delta (The Netherlands). Palaeogeography, Palaeoclimatology, Palaeoecology, 284: 355-374.

Bridge, J.S., 2003. Rivers and Floodplains: Forms, Processes, and Sedimentary Record. Blackwell Publishing, Malden.

Bristow, C.S., Skelly, R.L., Ethridge, F.G., 1999. Crevasse splays from the rapidly aggrading, sand-bed, braided Niobrara River Nebraska: effect of base-level rise. Sedimentology, 46: 1029-1047.

Burns, C., Mountney, N.P., Hodgson, D.M., Colombera, L., 2017. Anatomy and dimensions of fluvial crevasse-splay deposits: examples from the Cretaceous Castlegate Sandstone and Neslen Formation, Utah, U.S.A. Sedimentary Geology, 351: 21-35.

Cahoon, D.R., White, D.A., Lynch, J.C., 2011. Sediment infilling and wetland formation dynamics in an active crevasse splay of the Mississippi River delta. Geomorphology, 131: 57-68.

Chiarella, D., Moretti, M., Longhitano, S.G., Muto, F., 2016. Deformed cross-stratified deposits in the Early Pleistocene tidally-dominated Catanzaro strait-fill succession, Calabrian Arc (Southern Italy): triggering mechanisms and environmental significance. Sedimentary Geology, 344: 277-289.

Ciarcia, S., Vitale, S., 2013. Sedimentology, stratigraphy and tectonics of evolving wedge-top depozone: Ariano Basin, southern Apennines, Italy. Sedimentary Geology, 290: 27-46.
Collinson, J.D., Thompson, D.B., 1982. Sedimentary Structures. Allen and Unwin, London.

Davies-Vollum, K.S., Kraus, M.J., 2001. A relationship between alluvial backswamps and avulsion cycles: an example from the Willwood Formation of the Bighorn Basin, Wyoming. Sedimentary Geology, 140: 235-245.

Diessel, C., Boyd, R., Wadsworth, J., Leckie, D., Chalmers, G. 2000. On balanced and unbalanced accommodation/peat accumulations ratios in the Cretaceous coals from Gates Formation, Western Canada, and their sequence-stratigraphic significance. International Journal of Coal Geology, 43: 143-186.

Dżułyński, S., Walton, E.K., 1965. Sedimentary Features of Flysch and Greywackes. Elsevier, Amsterdam.

Farrell, K.M., 2001. Geomorphology, facies architecture, and high-resolution, non-marine sequence stratigraphy in avulsion deposits, Cumberland Marshes, Saskatchewan. Sedimentary Geology, 139: 93-150.

Fielding, C.R., 1986. Fluvial channel and overbank deposits from the Westphalian of the Durham coalfield, NE England. Sedimentology, 33: 119-140.

Flores, R.M., 1993. Geologic and geomorphic controls of coal development in some Tertiary Rocky Mountain basins, USA. International Journal of Coal Geology, 23: 43-73.

Flores, R.M., 2013. Coal and Coalbed Gas: Fueling the Future. Elsevier, Waltman, MA.

Gębica, P., Sokołowski, T., 2001. Sedimentological interpretation of crevasse splays formed during the extreme 1997 flood in the upper Vistula river valley (South Poland). Annales Societatis Geologorum Poloniae, 71: 53-62.

Gouw, M.J.P., Autin, W.J., 2008. Alluvial architecture of the Holocene Lower Mississippi Valley (U.S.A.) and a comparison with the Rhine-Meuse delta (The Netherlands). Sedimentary Geology, 204: 106-121.

Gruszka, B., van Loon, A.J., 2007. Pleistocene glaciolacustrine breccias of seismic origin in an active graben (central Poland). Sedimentary Geology, 193: 93-104.

Gruszka, B., Zieliński, T., 1996. Gravity flow origin of glaciolacustrine sediments in a tectonically active basin (Pleistocene, 
central Poland). Annales Societatis Geologorum Poloniae, 66 59-81.

Guion, P.D., 1984. Crevasse splay deposits and roof-rock quality in the Three Quarters Seam (Carboniferous) in the East Midlands Coalfield, U.K. Sedimentology of Coal and Coal-bearing Sequences. International Association of Sedimentologists, Special Publication, 7: 291-308.

Holdgate, G.R., 2005. Geological processes that control lateral and vertical variability in coal seam moisture contents - Latrobe Valley (Gippsland Basin) Australia. International Journal of Coal Geology, 63: 130-155.

Holzer, T.M., Clark, M.M., 1993. Sand boils without earthquakes. Geology, 21: 873-876.

Horne, J.C., Ferm, J.C., Caruccio, F.T., Baganz, B.P., 1978 Depositional models in coal exploration and mine planning in Appalachian Region. American Association of Petroleum Geologist Bulletin, 62: 2379-2411.

Kasiński, J.R., 1986. Sedimentary models of small lignite deposits: examples from the Polish Neogene (in Polish with English summary). Przegląd Geologiczny, 34: 189-197.

Kasiński, J.R., 1989. Lacustrine sedimentary sequences in the Polish Miocene lignite-bearing basins - facies distribution and sedimentary development. Palaeogeography, Palaeoclimatology, Palaeoecology, 70: 287-304.

Kasiński, J.R., Słodkowska, B., 2016. Factors controlling Cenozoic anthracogenesis in the Polish Lowlands. Geological Quarterly, 60 (4): 959-974.

Kirschbaum, M.A., McCabe, P.J., 1992. Controls on the formation of coal and on the development of anastomosed fluvial systems in the Cretaceous Dakota Formation of southern Utah. Sedimentology, 39: 581-598.

Kwiecińska, B., Wagner, M., 1997. Classification of qualitative features of brown coal from Polish deposits according to petrographical, chemical and technological criteria (in Polish with English summary). Wydawnictwo Centrum PPGSMiE Polskiej Akademii Nauk, Kraków.

Mach, K., Sýkorová, I., Konzalová, M., Opluštil, S., 2013. Effect of relative lake-level changes in mire-lake system on the petrographic and floristic compositions of a coal seam, in the Most Basin (Miocene), Czech Republic. International Journal of Coal Geology, 105: 120-136.

Markič, M., Sachsenhofer, R.F., 1997. Petrographic composition and depositional environments of the Pliocene Velenje lignite seam (Slovenia). International Journal of Coal Geology, 33: 229-254.

Mastej, W., Bartuś, T., Rydlewski, J., 2015. Analysis of facies cyclicity in the Miocene Coal Complex of the Bełchatów lignite deposit, south-central Poland. Geologos, 21: 285-302.

McCabe, P.J., 1984. Depositional models of coal and coal-bearing strata. International Association of Sedimentologists, Special Publication, 7: 13-42.

Miall, A.D., 1977. A review of the braided-river depositional environment. Earth-Science Reviews, 13: 1-62.

Michaelsen, P., Henderson, R.A., Crosdale, P.J., Mikkelsen, S.O., 2000. Facies architecture and depositional dynamics of the Upper Permian rangal coal measures, Bowen Basin, Australia. Journal of Sedimentary Research, 70: 879-895.

Moretti, M., Sabato, L., 2007. Recognition of trigger mechanisms for soft-sediment deformation in the Pleistocene lacustrine deposits of the Sant'Arcangelo Basin (southern Italy): seismic shock vs overloading. Sedimentary Geology, 196: 31-45.

Moretti, M., van Loon, A.J., 2014. Restrictions to the application of "diagnostic" criteria for recognizing ancient seismites. Journal of Palaeogeography, 3: 162-173.

Moretti, M., Alfaro, P., Caselles, O., Canas, J.A., 1999. Modelling seismites with a digital shaking table. Tectonophysics, 304: 369-383.

Moretti, M., Owen, G., Tropeano, M., 2011. Soft-sediment deformation induced by sinkhole activity in shallow marine environments: a fossil example in the Apulian Foreland (Southern Italy). Sedimentary Geology, 235: 331-342.
Moretti, M., Alfaro, P., Owen, G., 2016. The environmental significance of soft-sediment deformation structures: key signatures for sedimentary and tectonic processes. Sedimentary Geology, 344: $1-4$.

Obermeier, S.F., Pond, E.C., 1998. Issues in Using Liquefaction Features for Paleoseismic Analysis. United States Geological Survey Open-File Report: 98-28.

Obermeier, S.F., Olson, S.M., Green, R.A., 2005. Field occurrences of liquefaction-induced features: a primer for engineering geologic analysis of paleoseismic shaking. Engineering Geology, 76: 209-234.

Opluštil, S., 2005. The effect of paleotopography, tectonics and sediment supply on quality of coal seams in continental basins of central and western Bohemia (Westphalian), Czech Republic. International Journal of Coal Geology, 64: 173-203.

Owen, G., 1996. Experimental soft-sediment deformation: structures formed by liquefaction of unconsolidated sands and some ancient examples. Sedimentology, 43: 279-293.

Owen, G., Moretti, M., 2011. Identifying triggers for liquefaction-induced soft-sediment deformation in sands. Sedimentary Geology, 235: 141-147.

Owen, G., Moretti, M., Alfaro, P., 2011. Recognising triggers for soft-sediment deformation: current understanding and future directions. Sedimentary Geology, 235: 133-342.

Pérez-Arlucea, M., Smith, N.D., 1999. Depositional patterns following the 1870s avulsion of the Saskatchewan River (Cumberland Marshes, Saskatchewan, Canada). Journal of Sedimentary Research, 69: 62-73.

Piwocki, M., Ziembińska-Tworzydło, M., 1997. Neogene of the Polish Lowlands - lithostratigraphy and pollen-spore zones. Geological Quarterly, 41 (1): 21-40.

Rajchl, M., Uličný, D., 2005. Depositional record of an avulsive fluvial system controlled by peat compaction (Neogene, Most Basin, Czech Republic). Sedimentology, 52: 601-625.

Rajchl, M., Uličný, D., Mach, K., 2008. Interplay between tectonics and compaction in a rift-margin, lacustrine delta system: Miocene of the Eger Graben, Czech Republic. Sedimentology, 55: $1419-1447$.

Rossetti, D.F., Santos, A.E., 2003. Events of sediment deformation and mass failure in Upper Cretaceous estuarine deposits (Cametá Basin, northern Brazil) as evidence for seismic activity. Sedimentary Geology, 161: 107-130.

Schäfer, A., Hilger, D., Gross, G., von der Hocht, F., 1995. Cyclic sedimentation in Tertiary Lower-Rhine Basin (Germany) - the "Liegendrücken" of the brown-coal open-cast Fortuna mine. Sedimentary Geology, 103: 229-247.

Seilacher, A., 1969. Fault-graded beds interpreted as seismites. Sedimentology, 13: 15-159.

Shukla, M.K., Sharma, A., 2018. A brief review on breccia: it's contrasting origin and diagnostic signatures. Solid Earth Sciences, 3: $50-59$.

Sims, J.D., 1975. Determining earthquake recurrence intervals from deformational structures in young lacustrine sediments. Tectonophysics, 29: 141-152.

Słodkowska, B., Kasiński, J.R., 2016. Paleogene and Neogene a time of dynamic changes of climate (in Polish with English summary). Przegląd Geologiczny, 64: 15-25.

Słomka, T., Doktor, M., Wagner, M., Matl, K., 2000. Sedimentological study of Miocene alluvial fans in the Bełchatów lignite deposit (in Polish with English summary). Prace Geologiczne PAN, 147: 21-46.

Smith, N.D., Cross, T.A., Dufficy, J.P., Clough, S.R., 1989. Anatomy of an avulsion. Sedimentology, 36: 1-23.

Smith, N.D., Pérez-Arlucea, M., 1994. Fine-grained splay deposition in the avulsion belt of the lower Saskatchewan River, Canada. Journal of Sedimentary Research, B64: 159-168.

Spicer, R.A., Ahlberg, A., Herman, A.B., Kelley, S.P., Raikevich, M.I., Rees, P.M., 2002. Palaeoenvironment and ecology of the middle Cretaceous Grebenka flora of northeastern Asia. Palaeogeography, Palaeoclimatology, Palaeoecology, 184: 65-105. 
Teichmüller, M., 1989. The genesis of coal from the viewpoint of coal petrology. International Journal of Coal Geology, 12: 1-87.

Teisseyre, A.K., 1985. Recent overbank deposits of the Sudetic valleys, SW Poland. Part I: general environmental characteristics (with examples from the upper River Bóbr drainage basin) Geologia Sudetica, 20: 113-195.

Ticleanu, N., Scradeanu, D., Popa, M., Milutinovici, S., Popa, R., Preda, I., Ticleanu, M., Savu, C., Diaconita, D., Barus, T., Petrescu, I., Dinulescu, C., Maftei, R., 1999. The relation between the lithotypes of Pliocene coals from Oltenia and their main quality characteristics. Bulletin of the Czech Geological Survey, 74: 169-174.

Toonen, W.H.J., Van Asselen, S., Stouthamer, E., Smith, N.D. 2016. Depositional development of the Muskeg Lake crevasse splay in the Cumberland Marshes (Canada). Earth Surface Processes and Landforms, 41: 117-129.

Törő, B., Pratt, B.R., 2016. Sedimentary record of seismic events in the Eocene Green River Formation and its implications for regional tectonics on lake evolution (Bridger Basin, Wyoming). Sedimentary Geology, 344: 175-204.

Tye, R.S., Coleman, J.M., 1989. Evolution of Atchafalaya lacustrine deltas, south-central Louisiana. Sedimentary Geology, 65: 95-112.

Uličný, D., Rajchl, M., Mach, K., Dvořák, Z., 2000. Sedimentation and synsedimentary deformation in a rift-margin, lacustrine delta system: the Bílina Delta (Miocene), Most Basin. Proceedings of the 5th Meeting of the Czech tectonic Studies Group. Geolines, 10: 84-95.

Van Asselen, S., Stouthamer, E., Van Asch, Th.W.J., 2009. Effects of peat compaction on delta evolution: a review on processes, responses, measuring and modelling. Earth Science Reviews, 92: 35-51.

Van Loon, A.J., 2009. Soft-sediment deformation structures in siliciclastic sediments: an overview. Geologos, 15: 3-55.

Van Loon, A.J., Brodzikowski, K., Zieliński, T., 1995. Shock-induced resuspension deposits from a Pleistocene proglacial lake (Kleszczów Graben, central Poland). Journal of Sedimentary Research, A65: 417-422.

Widera, M., 2007. Lithostratigraphy and palaeotectonics of the Sub-Pleistocene Cenozoic of Wielkopolska (in Polish with English summary). Adam Mickiewicz University Press, Poznań.

Widera, M., 2012. Macroscopic lithotype characterisation of the 1st Middle-Polish (1st Lusatian) Lignite Seam in the Miocene of central Poland. Geologos, 18: 1-11.
Widera, M., 2013a. Sand- and mud-filled fluvial palaeochannels in the Wielkopolska Member of the Neogene Poznań Formation, central Poland. Annales Societatis Geologorum Poloniae, 83: 19-28.

Widera, M., 2013b. Changes of the lignite seam architecture - a case study from Polish lignite deposits. International Journal of Coal Geology, 114: 60-73.

Widera, M., 2014. Lignite cleat studies from the first Middle-Polish (first Lusatian) lignite seam in central Poland. International Journal of Coal Geology, 131: 227-238.

Widera, M., 2015. Compaction of lignite: a review of methods and results. Acta Geologica Polonica, 65: 367-368.

Widera, M., 2016a. Depositional environments of overbank sedimentation in the lignite-bearing Grey Clays Member: new evidence from Middle Miocene deposits of central Poland. Sedimentary Geology, 335: 150-165.

Widera, M., 2016b. An overview of lithotype associations forming the exploited lignite seams in Poland. Geologos, 22: 213-225.

Widera, M., 2016c. Characteristics and origin of deformations within the lignite seams - a case study from Polish opencast mines. Geological Quarterly, 60 (1): 181-191.

Widera, M., 2017. Sedimentary breccia formed atop a Miocene crevasse-splay succession in central Poland. Sedimentary Geology, 360: 96-104.

Widera, M., 2018. Tectonic and glaciotectonic deformations in the areas of Polish lignite deposits. Civil and Environmental Engineering Reports, 28: 182-193.

Widera, M., Hałuszczak, A., 2011. Stages of the Cenozoic tectonics in central Poland: examples from selected grabens. Zeitschrift der Deutschen Gesellschaft für Geowissenschaften, 162: 203-215.

Widera, M., Chomiak, L., Gradecki, D., Wachocki, R., 2017a. Crevasse splay deposits from the Miocene of central Poland near Konin (in Polish with English summary). Przeglad Geologiczny, 65: 251-258.

Widera, M., Kowalska, E., Fortuna, M., 2017b. A Miocene anastomosing river system in the area of Konin Lignite Mine, central Poland. Annales Societatis Geologorum Poloniae, 87: 157-168.

Zieliński, T., 2014. Sedymentologia. Osady rzek i jezior (in Polish). Adam Mickiewicz University Press, Poznań. 